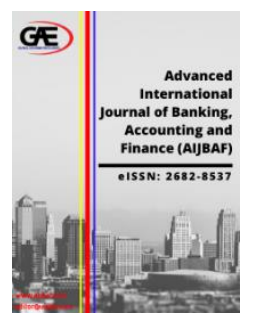

\author{
ADVANCED INTERNATIONAL JOURNAL OF \\ BANKING, ACCOUNTING AND FINANCE \\ (AIJBAF) \\ www.aijbaf.com
}

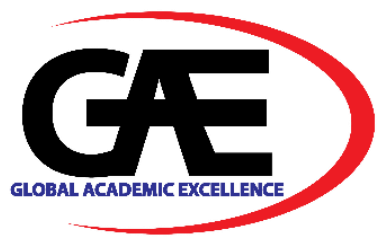

\title{
THE DISCLOSURE OF CORPORATE SOCIAL RESPONSIBILITY (CSR), BASED ON THE MAQASID AL- SHARIAH IN MALAYSIA AND MENA REGION
}

\author{
Nur Hanisah Razali ${ }^{1 *}$, Nizam Jaafar ${ }^{2}$, Ismail Ahmad ${ }^{3}$ \\ 1 Faculty of Business Management, Universiti Teknologi MARA, Malaysia \\ Email: anisah.mrazali@gmail.com \\ 2 Arshad Ayub Graduate Business School, Universiti Teknologi MARA, Malaysia \\ Email: mnizam7520@uitm.edu.my \\ 3 Department of Account, Universiti Teknologi MARA, Malaysia \\ Email: drismailahmad@uitm.edu.my \\ Corresponding Author
}

\section{Article Info:}

Article history:

Received date: 19.04.2021

Revised date: 25.04 .2021

Accepted date: 01.06.2021

Published date: 15.06 .2021

\section{To cite this document:}

Razali, N. H., Jaafar, N., \& Ahmad, I. (2021). The Disclosure Of Corporate Social Responsibility (CSR), Based On The Maqasid Al-Shariah In Malaysia And Mena Region. Advanced International Journal of Banking, Accounting, and Finance, 3 (7), 114-126.

\section{DOI: $10.35631 / A I J B A F .370010$}

This work is licensed under $\underline{\text { CC BY } 4.0}$

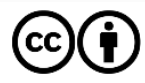

\begin{abstract}
:
Islamic Banking works in an economy and achieving the ideal position of Shariah financial institution requires continuous improvement and indicators. The right values and environment of a bank that is operating based on Shariah are important to ensure that the delivery services could be executed in the best manner possible. Islamic Bank therefore should embed with social and the charity work network for the purpose of its corporate social responsibility to the community. The fundamental issue which is due to the lack of focus on prioritising the social objective of Islamic organisations based on Shariah leads to the inadequacy of conventional CSR theories to underpin CSR practices of Islamic organisations. The existing concept of CSR is grounded on western perspectives, and it will be a great implication to delve into CSR within the Islamic perspectives. Therefore, the objective of this study to examine the extent of CSR based on Maqasid Al Shariah in terms of four dimensions of the Islamic Banks sector between Malaysia and the MENA region for the period of 2013 to 2018. This study employed a content analysis method to collect quantitative data on CSR based on Maqasid Al-Shariah in the Bank Islam annual report and stand-alone sustainability report. The content analysis was carried out to achieve this objective. The investigation on the content is based on CSR reporting in their annual report and stand-alone sustainability report according to what has been provided by the banks. The results of the analyses provide significant insight into the amount and nature of CSR among Islamic Banks across sectors. Generally, the CSR activities cover all organization activities related to the organization and its various stakeholder. Finally,
\end{abstract}


Volume 3 Issue 7 (June 2021) PP. 114-126

through mean score ranking for CSRD items shows that there was a mixed ranking for CSR based on Maqasid Al-Shariah dimension and element in Malaysia and MENA region.

Keywords:

Corporate Social Responsibility (CSR), Disclosure, Environment, Community, Workplace, Marketplace, Maqasid Al-Shariah

\section{Introduction}

In the early 1930s, Corporate Social Responsibility (CSR) had turned out to be part of a business plan for the sustenance, survival, and corporate development (Adamu \& Yusoff, 2016). Nowadays, the corporate social responsibility concept has grown to be a common practice which is not entirely due to regulation of a legal bodies but more on the custom practices of the organization around the world. However, many organizations remain unfamiliar with CSR (Rahim, Jalaludin, \& Tajuddin, 2011). Corporate firm in Malaysia views CSR as a strategic agenda in their company in a way to become good corporate citizen (Saleh, 2009).

According to Farook (2007) to gain legitimacy, CSR plan and practices in Islamic organization should be grounded on Islamic principles and laws as revealed in the Qur'an and Sunnah since the Islamic organizations their businesses operation is based on the Shariah principles. Therefore, this organizations which claim to act within the principles of Shariah should be clear about their CSR in relation to society. The prevailing CSR framework was invented in the context of the liberal market was articulated deprived of giving due consideration to the concept of Islamic laws and principles as enjoined in the Qur'an and the Sunnah. This study integrates the objectives of Shariah (Maqasid Al-Shariah) to know if the CSR policies and practices of Islamic organisations fulfil values as set out in Shariah and the extent of the Corporate Social Responsibilities Disclosure based on Maqasid Shariah in the Islamic Bank context.

\section{Literature Review}

Islam views on CSR instead is a universal approach. It is spiritual view from Qur'an and the Prophet's saying and practices (Sunnah) which is contrast to human theorist. It presents a framework for a person's interaction with nature and fellow human beings the principle is derived from legal evidence (Sunnah) and the Revelation that is the Quran. Therefore, the characteristic of this approach is enduring, eternal and absolute. In other words, it presents better guidelines for corporations executing their business and social responsibilities concurrently. One of the Islamic legal maxim which that is preventing harm, is relevant to CSR framework. As such, corporation must consider social responsibility and avoid business practices that can bring harm to the society's well-being at large.

CSR on Islamic perspectives assume a boarder and more holistic concept. The corporations are responsible to the customer, workers, managers, and society. They need to embrace the concept of taqwa by taking their responsibilities as servant and vicegerent of God in all circumstances (Dusuki \& Abdullah, 2007). A few verses in the Qur'an contains certain provisions which aim at attaining certain objectives (maqasid) intended by Allah as the law giver. It is proven that Allah does not act in vain as mentions in the Qur'an:"For (thus it is): we have not created the heavens and the earth and all that is between them in mere idle play. None of this have We 
Volume 3 Issue 7 (June 2021) PP. 114-126

DOI 10.35631/AIJBAF.370010

created without (an inner) truth: but most of them do not understand it". (Qur'an: Ad-Dukhan: 44, verse: $38-39$ )

Therefore, this ayah explain that all of the creation of Allah has value and purpose. Which respect to the creation of man and Islam as the last revelation given to them, Allah has explicitly stated that "This day I have perfected for you your religion and I have completed my bounties and I am pleased with the religion of Peace (Islam)" (Qur'an: Al-Maidah: 5, verse: 3). Therefore, the prime objectives of Shariah have been developed by a few Muslim scholars including Al- Ghazali. According to Al-Ghazali, the objectives of shariah is to foster wellbeing of all mankind which is in safeguarding their faith (deen), their lives (nafs), their minds (aql), their posterity (nasl) and their properties (mal). Any deeds which safeguard any of these five objectives of Shariah serve public interest and therefore, is considered desirable. (AlMaisawy, 1998).

The doctrine of Maqasid Al-Shariah as put forward predominantly by Al-Ghazali and AlShatibi are valuable reference points for the purpose of developing choices and preferences from the Islamic perspective (Jalil, 2006). These concepts can be seamlessly imported into the notion of conventional CSR to become an integral part of the Islamic perspective of CSR and subsequently adopted by business corporations that claim to comply with Shariah based principles such as Islamic banks. The discussion on how CSR being integrate in corporate firm are discussed below.

The disclosure of CSR data by Islamic banks will be influenced by a variety of other issues, all of which must be considered when focusing on the role of information and disclosure in relationships between organisations, the state, individuals, groups, and, most importantly, the Islamic society (Owen, 2005). As a result, two elements from systems-oriented theories have been found as having a direct impact on the level of CSR disclosure by Islamic banks. The first element, which is reflected by the political rights and civil liberties variable, is based on political economy theory, and focuses on the larger social and political environments in which organisations interact (Williams, 1999). Newson and Deegan (2002) also added that the second component, which is proxied by the variable relative number of Muslim populations, is derived from legitimacy theory and aims to represent the concept of the relevant publics from which the organisation requires legitimacy to exist. (Newson and Deegan, 2002).

As a result, it is recommended that all Islamic banks guarantee that their existence is recognised and that their contributions are counted by revealing any CSR programmes they are participating in or have launched in any media they have available, particularly in their annual report. This research backs up the claim made by Nik Ahmad et al. (2003) that making CSR disclosures mandatory will drive corporations to report on their CSR performance. This would also assist stakeholders by making yearly reports more uniform and comparable (Nik Ahmad et al., 2003), and by allowing them to analyse the non-financial benefits of CSR initiatives in a meaningful way. (Ackers \& Eccles, 2015).

It is also found that the companies disclose more on quantitative environmental information in 2009. This finding aligns with aa recent study from Ridzwan, Liu Kim, Rosmila \& Yusniyati (2016) on the quantity and quality of environment disclosure among environmentally sensitive companies in Malaysia for the year 2012. In supporting the legitimacy and institutional theories, it is found that the level of environmental disclosure by sampled companies is low. 
Volume 3 Issue 7 (June 2021) PP. 114-126

DOI 10.35631/AIJBAF.370010

Moreover, the information is disclosed in declarative form. Only a few companies disclosed comprehensive information in their annual reports.

Furthermore, Rosli \& Mohd (2015) establish that the size of a company and profitability are positively correlated with the CSRD. Ismail et al., (2015) find the legal responsibility is ranked as the most important aspect while ethical responsibility as the least important aspect of the CSR programmes of community development. The initiative related to education is the most dominant type of CSR information. It is believed that companies are aware of the necessity to complement the government's effort to raise adult literacy. Concerning the legal responsibility, companies are expected to obey the relevant laws and regulations such as Environment Quality Act (1974). Anti-corruption Act (1977) and the Human Rights Commission of Malaysia Act (1999).

Farook et.al (2011) also found other factors that have influences on the level of CSR disclosure in Islamic banks are the level of political and civil pressure. Based on the above studies. Another study conducted by Meutia and Febrianti (2016) conducted a research on purpose to compare the amount of CSR disclosure in Islamic banking in Indonesia and Malaysia. This research reveals that the level Islamic Social Reporting of Islamic banking in Indonesia is better than the level ISR of Islamic banking in Malaysia, based on data from annual reports from seven public Islamic banks in Indonesia and seven public Islamic banks in Malaysia. When it came to the overall topic of reporting, there were considerable disparities between the two groups.

Prior studies have implemented different CSR indices and dimensions to measure the extent and quality of CSRD. This leads to varying findings and conclusion which therefore, the findings are not consistent and unreliable for use in other scope of studies (Waddock, Graves \& Carroll, 1997). For the purpose of this study, the CSR measurement is developed from the CSRD item and checklist. The disclosure covers four areas outlined by Bursa Malaysia which are community, environment, marketplace, and workplace. This study will focus on the nature and extent of CSRD among Malaysian Islamic Bank and Islamic Bank at MENA region. This study will extend previous studies by comprehend the Maqasid Al-Shariah element into CSR. Today, CSR has become popular topic of studies (Yusoff \& Fauziah, 2016). Despite the extensiveness of the studies on CSR in Malaysia, the studies mostly concentrated on the effectiveness of CSRD, perception of CSR, development of CSR reporting and comparison between Malaysia and other countries. Thus, it is believed that there is still gap in the research of CSRD in Malaysian contact, in addition regarding the CSR based on Maqasid Al-Shariah.

\section{Methodology}

The population of the study comprises of Islamic Banks in Malaysia and MENA Region. The secondary data are obtained from reliable sources such as Bank Annual Report, Sustainable Report of Islamic Bank, and Islamic banks' website to gain information and better understanding regarding CSR framework. This study uses financial data of the Islamic banks listed in Bank Negara Malaysia (BNM) and World Database for Islamic Banking and Finance. The list of the Islamic banks selected based on the availability of the CSR data from the cited sources. By using annual data, the information is gathered for five years starting from 2011 to 2017. The listed Islamic bank in Malaysia is included in this study which are: 
Volume 3 Issue 7 (June 2021) PP. 114-126

DOI 10.35631/AIJBAF.370010

\begin{tabular}{clc}
\hline No. & Name & \\
\hline \multicolumn{2}{c}{ Malaysia } & Ownership \\
1 & Ambank Islamic Berhad & $\mathrm{L}$ \\
2 & Bank Islam Malaysia Berhad & $\mathrm{L}$ \\
3 & Bank Rakyat Berhad & $\mathrm{L}$ \\
4 & CIMB Islamic Bank Berhad & $\mathrm{L}$ \\
5 & RHB Islamic Bank Berhad & $\mathrm{L}$ \\
6 & Hong Leong Islamic Bank Berhad & $\mathrm{L}$ \\
7 & Maybank Islamic Berhad & $\mathrm{L}$ \\
8 & Public Bank Islamic Berhad & $\mathrm{L}$ \\
& & \\
MENA Region & Country \\
1 & Abu Dhabi Islamic Bank & UAE \\
2 & Emirates Bank & UAE \\
3 & Islamic Development Bank & Saudi Arabia \\
4 & Jordan Islamic Bank & Jordan \\
5 & Qatar Islamic Bank & Qatar \\
6 & Bank Mellat & Iran \\
7 & Bahrain Islamic Bank & Bahrain \\
\hline
\end{tabular}

\section{Measurement of Corporate Social Responsibility based on Maqasid Al-Shariah}

Corporate Social Responsibility (CSR) is more tough to measure compared to corporate financial performance because it may reflect an approach. Corporate social performance is most commonly to referred as CSR measurement. Different researcher has used varying methods to measure CSR performance. Based on literature review, there are four common methods used to measure CSR in the previous studies (Mishra \& Suar, 2010; Preston \& Bannon, 1997; Waddock, Graves and Carrol 1997; Aupperle, 1991; Cochran \& Wood, 1984). These are company rating approach, survey methodology, reputation indices and content analysis. According to Chatterji, Levine and Toffel (2009) in Kinder, Lydneberg, Domini (KLD), these are the most common approach used to measure social and environmental performance ratings. They clarified company performance and reputation can be revealed through the social and environment rating. Furthermore, these social and environment rating able the interested parties to distinguish environmentally friendly companies as the transparency provided. In addition, the ratings are useful for the investors to analyse and assess the company's past performance and support the managerial decision making.

The researcher develops the CSR measure to suit the needs of their own country. Nevertheless, two mostly common recognized methods are reputation index and content analysis. A reputation index is where an expert observes rates firms based on one or more dimensions of social performance. Moskowits, 1972 had formulated reputation index which rated several companies as an outstanding, honourable mention, or worst over a period of several years. Nevertheless, Mahoney and Thorn (2006) disputed the reliability of the reputation indices on CSP using KLD rating. As suggested by Cochran \& Wood (1984), the rankings are very subjective, and results may be varied since it heavily depends on the observer's estimation. Thus, this might lead to inconsistent result. 
Volume 3 Issue 7 (June 2021) PP. 114-126

DOI 10.35631/AIJBAF.370010

Past studies had widely used content analysis to measure the CSR quantity (Hackston \& Milne,1996). The method identifies and describes patterns on specified social responsibilities reported in websites, annual report, and stand-alone sustainability report. It is technique of codifying the presence of certain words or concepts within sets of text. Various authors (Weber, 1990) proposed a formula definition for content analysis. Kriffpendorff (1980) describes research technique for making a valid inference from the data according to their content as the definition of content analysis. Meanwhile, Weber (1990) explains content analysis as a method of codifying content or text of a piece of writing intro a variety of group or classification depending on the selection criteria.

There are several ways of codifying the CSR information into quantitative measurement such as counting the number of words (Deegan \& Gorfdon, 1996) number of sentences (Tsang 1998; Milne \& Adler, 1999; Gray et. al, 1995; Patten, 1991). Generally, there is no common standard of content analysis that can be applied to evaluate the reliability of CSR. The reliability of content analysis seems to be questionable and heavily criticised in the previous studies (Milne \& Adler, 1999). Unerman (2000) also highlight the reliability and validity of content analysis need to be pondered.

Although there are different indices available (FTSE4Good Index, Dow Jones Sustainability Index), however in the context of developing countries since the measurement cannot be directly applied as it is based on the international CSR standards for developed country. Therefore, this research will employ CSR based on Maqasid Al-Shariah scoring index process to quantify the CSR-i by examining the Islamic Banks annual report and stand-alone sustainability report.

\begin{tabular}{|c|c|c|}
\hline Method & Argument & Prior Studies \\
\hline Word & $\begin{array}{l}\text { It is questionable as individual words do } \\
\text { not convey any meaning without the } \\
\text { sentence to provide the content }\end{array}$ & $\begin{array}{ll}\text { - } & \text { Milne \& Adler (1990) } \\
\text { - } & \text { Tilt (1994) } \\
\text { - Zeghal \& Ahmed } \\
\\
\text { (1990) } \\
\text { - Wilmshurst \& Frost } \\
\text { (2000) } \\
\text { - Kimboro \& Melendy } \\
\text { (2010) }\end{array}$ \\
\hline Sentence & $\begin{array}{l}\text { It suffers less judgment compared with } \\
\text { word measurement. }\end{array}$ & $\begin{array}{ll}\text { - } & \text { Ingram \& Frazier } \\
& (1980) \\
\text { - } & \text { Tsang (1998) } \\
\text { - } & \text { Unerman (2000) } \\
\text { - } & \text { Saleh, Zulkifli \& } \\
& \text { Muhamad, 2010 }\end{array}$ \\
\hline Page & $\begin{array}{l}\text { The element of subjectivity due to } \\
\text { differences in font size, margin and size } \\
\text { of the graphics. } \\
\text { The variance of company annual report } \\
\text { in terms of quality and format between } \\
\text { one to another. }\end{array}$ & $\begin{array}{ll}\text { - } & \text { Hackston \& Milne } \\
& (1996) \\
\text { - } & \text { Tilt (1994) } \\
\text { - } & \\
\text { Belal (2014) }\end{array}$ \\
\hline
\end{tabular}




\section{Content Analysis (CA)}

This study employed content analysis method to collect quantitative data on CSR based on Maqasid Al-Shariah in the Bank Islam annual report and stand-alone sustainability report. According to Neuman (2014), content analysis is a technique for analysing the collected content of the text. The content denotes to any messages that can be communicated, ideas, themes, words or meaning.

Krippendorff (1980), extend the content analysis definition of as a replicable and systematic technique for encompassing many words of text into fewer content categories based on explicit rules of rules. Aside from the objectivity, systematically and reliability of gathered information, it is also crucial to ensure high level of external legitimacy and permit for greater volumes of data, which can be coded by multiple individuals if necessary (Gray et al., 1995). Prior study in investigating the degree of CSR disclosure for several items had used the content analysis method. (Zainal et al., 2013)

To determine the extent of CSR based on Maqasid Al-Shariah of the firms, a content analysis was performed to analyse the annual report and stand-alone sustainability report. It was conducted by gathering qualitative data from annual report and stand-alone sustainability report and converting it into quantitative score.

\section{Results and Discussions}

Cross country analysis Score and Ranking Disclosure (CSRD) Items based on Maqasid AlShariah for Malaysia and MENA Region.

\begin{tabular}{|c|c|c|c|c|}
\hline \multirow[b]{2}{*}{ Items } & \multicolumn{2}{|c|}{ Malaysia } & \multicolumn{2}{|c|}{ Mena Region } \\
\hline & Mean & Ranking & Mean & Ranking \\
\hline \multicolumn{5}{|l|}{ Workplace } \\
\hline $\begin{array}{l}\text { W1. Providing adequate training, maintaining } \\
\text { equipment in good working condition, } \\
\text { maintaining a safe working environment. }\end{array}$ & 3.5714 & 1 & 3.0000 & 1 \\
\hline W2. Protecting in health and safety & 2.4286 & 3 & 0.6944 & 3 \\
\hline $\begin{array}{l}\text { W3. Treating employees fairly in terms of wages, } \\
\text { working hours }\end{array}$ & 1.5714 & 5 & 0.6944 & 4 \\
\hline W4. Investing in education and training. & 3.4286 & 2 & 1.7500 & 2 \\
\hline $\begin{array}{l}\text { W5. Respecting workers' rights, dealing with } \\
\text { workers problems quickly and fairly. }\end{array}$ & 0.8571 & 6 & 0.3611 & 6 \\
\hline W6. Ensuring operation respect human rights & 0.5714 & 7 & 0.2500 & 7 \\
\hline $\begin{array}{l}\text { W7. Refrain lending to oppressive regime or } \\
\text { companies violating human rights. }\end{array}$ & 1.7143 & 4 & 0.6944 & 5 \\
\hline \multicolumn{5}{|l|}{ Environment } \\
\hline $\begin{array}{l}\text { E1. Good pollution control, waste and recycle } \\
\text { policy }\end{array}$ & 2.8571 & 2 & 0.6389 & 3 \\
\hline E2. Energy conservation & 3.0000 & 1 & 0.8611 & 1 \\
\hline E3. Not doing things that harm the environment & 0.7143 & 4 & 0.2222 & 4 \\
\hline $\begin{array}{l}\text { E4. Undertake initiatives to promote } \\
\text { environmental responsibility }\end{array}$ & 2.7143 & 3 & 0.8056 & 2 \\
\hline
\end{tabular}


Volume 3 Issue 7 (June 2021) PP. 114-126

DOI 10.35631/AIJBAF.370010

\section{Society}

C1. Help solve social problems

$1.7143 \quad 3$

$1.0000 \quad 3$

C2. Supporting charities and community projects

4.00001

$2.7500 \quad 2$

C3. Participate in management of public affairs

$0.2857 \quad 4$

$0.9722 \quad 4$

C4. Play a role on society goes beyond profit

4.00002

2.97221 maximization

\section{Marketplace}

M1. Declaration of quality, safety and hygienic

$2.1429 \quad 3$

0.63892 production process.

$\begin{array}{lllll}\text { M2. Fair prices } & 0.2857 & 6 & 0.5556 & 3 \\ \text { M3. Provision of Halal products and services } & 3.2857 & 1 & 1.3056 & 1 \\ \text { M4. Fair trading relationship } & 1.4286 & 5 & 0.0000 & 6 \\ \text { M5. Environmentally friendly products and } 2.2857 & 2 & 0.3056 & 4 \\ \begin{array}{l}\text { services } \\ \text { M6. Protection of health and safety of the } 1.5714\end{array} & 4 & 0.1944 & 5\end{array}$
consumers.

Based on table above, for the workplace dimension Islamic Bank Malaysia and MENA region accentuate on providing adequate training for their worker, maintaining equipment in good working condition and ensure their employee working in a safe working environment. This is proven by the highest mean values for this item disclose by the Islamic Banks in their annual report or stand-alone report. However, in term of treating the employee wages and working hour fairly, MENA region emphasized on this item more that Malaysia Islamic Banks as Malaysia concern more on refrain lending to oppressive regime or companies violating human right. Malaysia and MENA share same least concern on the items of ensuring the operation respect human rights.

Under the environment dimension both highest mean score for Malaysia and MENA region are positioned on the energy conservation items. MENA regions play an active role in undertaking initiative to promote environmental responsibility meanwhile Malaysia concern more on good pollution control, waste and recycle policy. While, both regions are least concern on prevention of doing anything that can harm the environment.

Community dimensions have slightly different result between MENA and Malaysia. Malaysia the highest mean score was share by the item supporting charities and community project. These two elements play an active role towards the community which go beyond profit maximization. Meanwhile, in MENA region emphasized the organization played a role on society goes beyond profit maximization as result showed the highest score under community dimension. Both share the lowest ranked items on their participation in public affairs management.

Apart from that, the observation continued for marketplace dimension disclosure. Information on the provision of Halal products and service ranked the highest among other remarkable disclosure items for both regions. However, the ranking is varied between both country and regions. Information on environmentally friendly products and services ranked the second highest for Malaysia while fair prices showed the lowest ranked disclose by the Islamic Banks. Meanwhile, MENA region emphasize more on declaration of quality, safety and hygienic 
Volume 3 Issue 7 (June 2021) PP. 114-126

DOI 10.35631/AIJBAF.370010

production process and they are ranked as the second highest. Information on fair trading relationship with their stakeholders is the least disclosed by the MENA region Islamic banks.

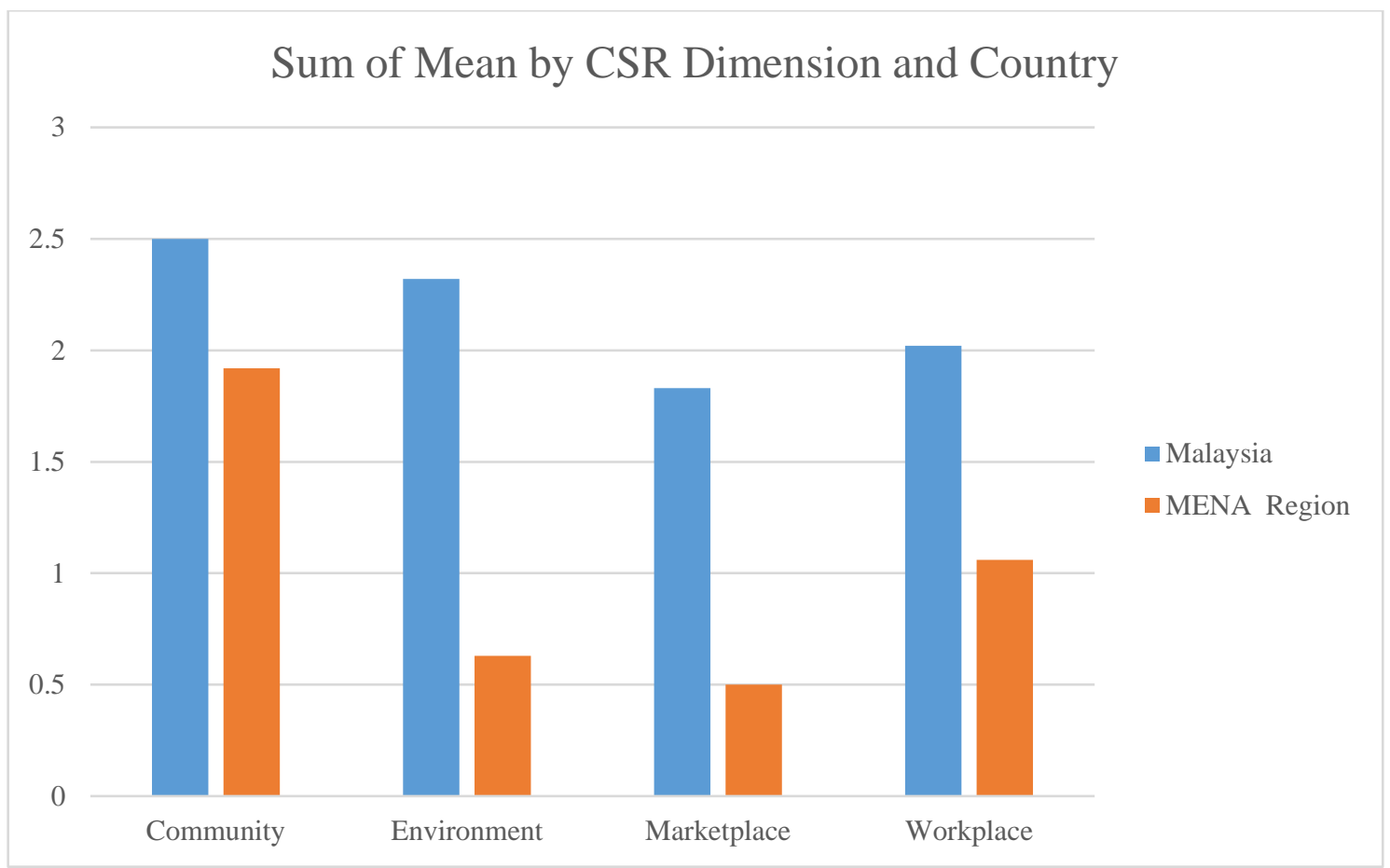

Through the content analysis conducted on 7 Islamic Banks in Malaysia and 6 Islamic Bank in MENA regions for the period of 2013 to 2018 with total 78 observation, table above shows the trends of CSRD based on Maqasid Al-Shariah. The result found that, community dimension is the highest and marketplace as the lowest ranked on CSR based on Maqasid Shariah for both Malaysia and MENA region. However, MENA region second highest ranking is workplace while Malaysia shows environment as the second highest ranked disclosure items. Overall charts show that Malaysia have the higher means score in all dimensions compare to MENA region.

Firstly, the most common CSR dimension by all samples was community information. It was found that Islamic Banks does give active support towards charities and community projects. This is followed by the workplace dimension which revealed that the banks provide adequate training, maintaining equipment in good working condition, and maintaining a safe working environment. These are the elements that become preference of the samples. Furthermore, information on energy conservation was the most disclosed under environment dimensions. As expected from the common observation, it was found that marketplace dimension is the least disclosed. However, information on declaration of quality and friendly of the product was modestly being disclosed. Through the content analysis, it is believed that the awareness in disclosing CSR information pertaining to marketplace is still minimal among the samples.

Secondly based on the cross-country analysis, it was found that Islamic Banks in Malaysia disclosed their CSR more and play active role the most in CSR initiative compared to the MENA region. 


\section{Conclusion}

This study is examining the nature and extend of CSR-i among Malaysian and MENA Region Islamic Banks. Information on community dimension is the highest disclosed followed by workplace, environment, and marketplace dimension. From the observation, there are companies who have not disclosed any information on any of CSR dimensions. This is consistent with Anas et al., (2015) who found the community dimensions is the mostly disclosed in their study.

The difference of closure between the region varies depending on the nature of their business operation as well as their CSR policies in particular Islamic Banks. Based on the finding, the workplace dimension was the most disclosed information for all Islamic Banks. The result indicates that those employees have been recognized as an important asset in the business operation. Thus, it is imperative for the organization taking care the utmost well-being of their employees. However, information on marketplace dimension was the least information found across the sectors. Lacking awareness and motivation could be the reason why the companies did not give priority on this information. For instance, the company may not realize on how such information which marketplace related information is could assist them in enhancing their business reputation as well as reducing their business risk.

With regard on the extent of community dimension among Malaysian and MENA Region Islamic Bank information on 'philanthropy engagement' and 'play a role on society goes beyond profit maximization' are commonly found in the reports while, information on 'participation in management of public affairs is the least information being disclosed. Furthermore, on the environment dimension it reveals that resources conservation and resource efficiency, 'environmental stewardship' and 'environmental recognition' are the most preferred information being disclosed. However, the information on water management is the poorly disclosed. On the marketplace dimension, information on 'provision of Halal products and services' are easily found in their reports while information on 'fair trading relationship' is poorly disclosed in MENA while in Malaysia information on fair prices is poorly disclosed. Moreover, with respect of workplace dimension information on 'provide adequate training with equipment in good condition while maintaining a safe working environment' and 'investing in education and training' are the most popular items being disclosed but similarly information on 'ensuring operation respect human rights' is the least information found in both region Malaysia and MENA.

Based on the result show that, Malaysia more adheres to CSR based on Maqasid Al-Shariah compared to MENA region. This due to the requirement outline by Bursa Saham Malaysia regards to CSR reporting for the company listed in Bursa Saham Malaysia.

There are several possible issues can be considered in future to produce and more meaningful outcomes. The data collected is only limited on the annual stand-alone sustainability reports. Future study could include information on CSR activities from various medium for instance the information published on the web site of a company. The measurement of the disclosure could be more accurate as more information is gathered. 
Volume 3 Issue 7 (June 2021) PP. 114-126 DOI 10.35631/AIJBAF.370010

\section{References}

Ackers, B., \& Eccles, N. S. (2015). Mandatory Corporate Social Responsibility Assurance Practices: The Case of King III in South Africa. Accounting, Auditing \& Accountability Journal, 28(4), 1-34

Adamu, M. S., \& Yusoff, W. W. (2016). The Relationship Between Corporate Social Responsibility and Company's Financial Performance: The Case of Top One Hundred Companies in Malaysia. Medwell Journals, 10(4), 345-351.

Al-Maisawy, M. T. (2006). IbnAshur Treatise on Maqasid al-Shari'ah. Kuala Lumpur: Islamic BookTrust (IBT)

Allouche, J., \& Laroche, P, (2005). A Meta-Analytical Investigation of the Relationship between Corporate Social and Financial Performance. Human Resource Management Review 57, 18-40.

Aribi, A. Z. (2009). Corporate Governance: The Impact of Director and Board Structure and Corporate Control on the Performance of Listed Companies on the Ghana 16 (2), 259277.

Anas, A., Rashid, A., H. M., \& Annuar, H. A(2015). The effect of Award on CSR Disclosure in Annual Reports of Malaysia PLCs. Social Responsibility Journal 11(1), 831-852

Belal, A. R., Abdelsalam, O., \& Nizamee, S. S. (2014). Ethical Reporting in Islami Bank Bangladesh Limited (1983-2010). Journal of Business Ethics, 129, 769-784.

Carroll, A. B. (1999). Corporate Social Responsibility: Evolution of a Definitional Construct. Business \& Society, 38(3), 268-295.

Dasuki, A. W., \& Abdullah, N. I. (2007). Maqasid al-Shari ah, Maslahah, and Corporate Social Responsibility. The American Journal of Islamic Social Sciences, 1, 24-45.

Farook, S. (2011). Social Responsibility for Islamic Financial Institutions: Laying Down A Framework. Journal of Islamic Economics, Banking and Finance. 4.

Freeman, R. E. (1984) Strategic Management A Stakeholder Approach. New Zealand: MA Pitman Books.

Gray, R., Kouhy, R., \& Laver, S.(1995). Corporate Social and Environmental Reporting: A reviewof the Literatureand Longitudinal Study of UK Disclosure. Accounting, Auditing \& Accountability Journal 8(2), 47-77.

Hackston, D. \& Milne, M. (1996). Some Determinants of Social and Environmental Disclosure in New Zealand Companies. Accounting, Auditing \& Accountability Journal, (9), 77108. 10.1108/09513579610109987.

Ingram, R.W., \& Frazier, K.B. (1980). Environmental Performance and Corporate Disclosure. Journal of Accounting Research, 18(2), 614-622

Ismail, M., Aias, S.U., \& Hassan, I (2012). Community as The Stakeholder of The Corporate Social Responsibility Programme in Malaysia: Outcome in Community Development. Social Responsibility Journal, 11(1), 109-103.

Jalil, A. (2006). "The Significances of Maslahah Concept and Doctrine of Maqasid (Objectives) al-Shari'ah in Project Evaluation". The Journal of Muamalat and Islamic Finance Research.

Jusoh, W. H. W., \& Ibrahim, U. (2017). Corporate Social Responsibility of Islamic Banks in Malaysia: Arising Issues. Islamic Economic Studies, 25, 155-172.

Kim, E., Nam, D., \& Stimpert, J. L. (2003). The applicability of Porter's generic strategies in the digital age: assumptions, conjectures, and suggestions. Journal of Management, 30, 569-90. 
Volume 3 Issue 7 (June 2021) PP. 114-126

DOI 10.35631/AIJBAF.370010

Kimboro, M.B., \& Melendy, S.R. (2010). Financial Performance and Voluntary Environmental Disclosures During The Asian Financial Crisis: The case of Hong Kong. International of Business Performance Management, 12(1)

Krippendorff, K. (1980), Content Analysis: An Introduction to Its Methodology, The Sage CommText Series, Sage, Beverly Hills, CA Kuwait Finance House. (2014) KFH Research Ltd. Islamic Finance Outlook.

McGuire, J.B., Sundgren, A., \& Schneeweis, T., (1988) Corporate Social Responsibility and Firm Financial Performance. The Academy of Management Journal 31 (4), 854-872.

Meutia, I. \& Febrianti, D. (2016) Islamic Social Reporting in Islamic Banking: Stakeholders Theory Perspective. SHS Web of Conferences, 34. https://doi.org/10.1051/shsconf/20173412001

Milne, M.J., \& Adler, R.W. (1999). Exploring the Reliability of Social and Environmental Disclosures Content Analysis. Journal of Business Ethics, 95.

Mohammed, Dzuljastri \& Taib. (2008). "The performance Measure of Islamic Banking Based on the Maqashid Framework". Paper of IIUM International Accounting Conference (INTACIV) held at Putrajaya Marriott.

Neuman, W.L. (2014). Social Research Methods: Qualitative and Quantative Approaches. Relevance of Social Research, 8.

Newson, M., \& Deegan, C. (2002). Global expectations and their association with corporate social disclosure practices in Australia, Singapore, and South Korea. International Journal of Accounting, 37(2), 183-213

Nik Ahmad, N. N., Sulaiman, M., \& Siswantoro, D. (2003). Corporate Social Responsibility Disclosure in Malaysia: An Analysis of Annual Reports of KLSE Listed Companies. IIUM Journal of Economics and Management, 11(1), 51-86.

Owen, D. (2005). CSR after Enron: A Role for the academic accounting profession? European Accounting Review. 14(2). 394-404. doi.10.1080/09638180500126892

Palmer, J.H. (2012). Corporate Social Responsibility and Financial Performance: Does it Pay to Be Good? CMC Senior Thesis.

Porter, M. E., \& Kramer, M. R. (2006). The link between competitive advantage and corporate social responsibility. Harvard business review, 84(12), 78-92.

Rahim, R. A., Jalaludin, F. W., \& Tajuddin, K. (2011). The Importance of Corporate Social Responsibility on Consumer Behaviour in Malaysia. Asian Academy of Management Journal, 16(1), 119-139.

Rahman, M. M., Rashid, M. M., \& Haque, M. R. (2014). Corporate Social Responsibility and Financial Performance: A Case Study of Jamuna Bank Limited,Bangladesh. Asian Journal of Finance \& Accounting, 6(2). doi:ISSN 1946-052X

Raihan, M. Z., Bakar, R., \& Islam, M. A. (2015). Impact of Corporate Social Responsibility (CSR) Expenditures on Financial Performance of Islamic Bank Bangladesh Ltd. Medwell Journals, 2(10), 171-177.

Riahi, B. A. (1992). Accrual Accounting, Modified Cash Basis of Accounting and Loan Decision: An Experiment in Functional Fixation. Managerial Finance 18(5), 3-13.

Ridzwana, M.S., Liu, K.L., Rosmila, S., \& Yusniyati, Y. (2016). Quantity and Quality of Environmental Disclosure by Environmental Sensitive Companies in Malaysia. International Business Management, 10(8), 4324-4350.

Roseland, M. (2012). Toward sustainable communities: Solutions for citizens and their Governments, 6. New Society Publishers, Gabriola Island. 
Volume 3 Issue 7 (June 2021) PP. 114-126 DOI 10.35631/AIJBAF.370010

Rosli, M.H., \& Mohd, F.b (2015). Determinants f CSR Disclosure: A Study on Malaysia Public Listed Companies. Annual International Conference In Accouting and Finance (November), 1-23

Rotolo, T., \& Wilson, J. (2006). Substitute or complement? Spousal influence on volunteering. Journal of Marriage and Family, 68(2), 305-319.

Saleh, M. (2009). Corporate social responsibility disclosure in an emerging market: A longitudinal analysis approach. International Business Research, 2(1), 131-141.

Saleh, M., Zulkifli, N., \& Muhammad, R. (2011). Looking for the evidence of the Relationship Between Corporate Social Responsibility and Corporate Financial Performance in an Emerging Market. Asia-Pacific Journal of Business Adminsistration, 3(2), 165-190.

Satish, J., \& Li, Y. (2016). What Is Corporate Sustainability and How Do Firms Practice It? A Management Accounting Research Perspective. Journal of Management Accounting Research,28 (2): 1-11. doi: https://doi.org/10.2308/jmar-10496

Sunwoo, H. Y., Law, J., Lee, W.J., \& Oh, S. (2020) The importance of organizational context for the relation between human capital investment and firm performance: Evidence from labor unions. Journal of Management Accounting Research. doi: https://doi.org/10.2308/jmar-19-009

Tsang, E.W.K (1998). Alongitudinal Study of Corporate Social Reporting in Singapore: The case of the Banking, Food and Beverages and Hotel Industires. Accounting, Auditing \& Accounting Journal, 11(5), 624-635

Tilt, C.A. (1994). The influence of External Pressure Groups on Corporate Social Disclosure: Some Empirical Evidnece. Accounting, Auditing \& Accountability Journal, 7(4), 4772.

Unerman, J. (2000). Methodological Issues - Reflections on Quantifcation inn Corporate Social Reporting Content Analysis. Accounting, Auditing \& Accountability Journal, 11(4), 749-763.

Waddock, S.A. \& Graves, S.B., (1997). The corporate social performance - financial performance link. Strategic Management Journal 18(4), 303-319.

Wilmshurst T. and Frost G, (2000). The adoption of environment related management accounting. An analysis of corporate environment sensitivity. Accounting Forum 24(4), 344-365.

Yusoff. W., \& Fauziah. W. (2016). The Relationship Between Corporate Social Responsibility and Firm Performance: Evidence from Malaysia. International Business Management. 10. 345-351. 10.3923/ibm.2016.345.351.

Zainal, D., Zulkifli, N., \& Saleh, Z. (2013). Corporate Social Responsibility Reporting in Malaysia: A comparison Between Shariah and Non-Shariah Approved Firm. MiddleEast Journal of Scientific Research, 15(7), 1035-1046

Żak, A. (2015). Social Responsibility of Organizations Directions of Changes. (M. RojekNowosielska, Publishing House of Cracow University of Economics. doi:0.15611/pn.2015.387.21

Zeghal, D., \& Ahmad,S. (1990). Comparisons of Social Responsibility Information Disclosure Media Used by Canadian Firms. Accounting, Auditing \& Accountability Journal, 3(1), $38-53$. 